\title{
Examination of Corporal Punishment from Three Perspectives: A Recommended Corporal Punishment Counseling Model and its Application
}

\author{
Ayla Akbash \\ Kocaeli University, Turkey
}

\section{Introduction}

Corporal punishment [(beating, physical violence)] is a consequence of accumulations which have continued throughout the human history. According to Gözütok (1993), corporal punishment is the infliction of pain or harm on a person's body as retribution for an offence. According to Köknel (1996), on the other hand, it is an aggression instinct which has dominated the society without being limited any pressure, control or obstruction. According to Egerton (1976) it is an ineffective method of changing a child's behavior. According to Baler (1988), it is the expression of weakness. According to the author, corporal punishment is the transfer of a person's feelings of inadequacy related to his expectation from other people to act according to his feelings, thoughts and behaviors; to self-expression, and to perceiving other people's needs, emotions, thoughts and actions to behaviors along with aggressive tendencies.

In corporal punishment, the primary responsibility falls on the father (Paley, 1979; Riak, 1979). It was discovered that rather than the family structure, or having a single parent or both parents, it was mental health and psycho-social and economic pressures that resulted in corporal punishment towards the child (Nobes and Smith, 2000 ; 2002). Corporal punishment has become a universal phenomenon which is applied by everyone (Elliman and A. Lynch, 2013). Corporal punishment is being used as a disciplinary method (Taylor et al; 2012). It is very important that the family is open to accepting help in all kinds social environments for the transformation of negative behavior patterns observed in parent-child relations into positive ones. In effective disciplinary behaviors, the corporal punishment must be restricted (Dinkmeyer, 1982, Committee on Psychosocial Aspects of Child and Family Health, 1998) and effective guidance services must be provided to families. 


\section{Corporal Punishment according to Personality Theories}

1. According to the Psychoanalytic Theory; (Figure 1) the instincts which motivate and orient the behaviors are the sources of all actions and the psychological expression of internal and organic stimulation (need) is desire.

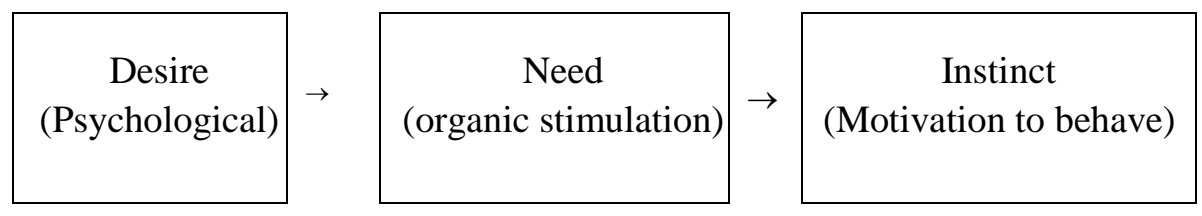

Figure 1. Dimensions of Instincts

\section{Instinct Theory}

At the beginning, instincts were categorized into two groups (1) Sexual (aiming for the continuation of the species) (2) Ego (protection of the individual). Aggression which constitutes the foundation of corporal punishment was believed to be equivalent to sadism. At first it was believed that it was related to sexual instincts. Then it was considered within the ego - self-protection instincts. As a result, aggression was believed to be a defense behavior.

Later, Freud put forth the "death instinct" concept at a philosophical level and changed the instinct theory. This leads to the categorization of instincts as (1) Life (sexual and ego - self-protection), and (2) Death (self-destruction).

In the instinct theory there are (1) id and ego, (2) loving an object and oneself, (3) life and death instincts. Despite the contradiction among these instincts, when Freud accepted ego as an object, it became impossible to differentiate the libido directed towards the ego - particularly the sadistic tendencies in it - from ego's self-protection instincts.

When libido and ego are categorized under the life instinct as a single concept, contradictions arises between the self-destruction instinct of the libido and the selfprotection instinct of the ego; and the ego's self-protection tendency and its desire to control and dominate the environment. At the beginning, aggression related to narcissism reaches a dead end because of the libidinal energy dependent upon the ego definition at the pregenital period. The premise that ego's characteristic of dominating the environment allowed the individual to feel safe, and as a result the sadistic elements in the libido were tied to the ego instinct, making them 
Ayla Akbash

compatible was based on the modifiability of the instincts. The ego which provides the self-protection energy neutralizes the energy released by aggression (Hyman, 1990). However, Freud attributed aggression to the existence of a new instinct because of its destructive nature.

With the libidinal energy, the life instinct ensures the continuation of individual life and the human species. As a result of the death wish in the subconscious, the death instinct directs the purpose of life to death, and the purpose of aggression to destruction. The assumption is based on the principle that all organic life eventually is transformed to inorganic continuity.

Life and death instincts are aimed at pleasure. The pleasure in death is reaching nirvana. There is endless peace and unchanging balance in nirvana (Ertan and Ardal1, 1996). Love is a derivative of the sexual instinct whereas hate and aggression are derivatives of the death instinct. As a result of the flexibility and modifiability of instincts, twinned emotions can neutralize or replace each other.

\section{Aggression}

Aggression is a forceful, violent, destructive behavior which aims to dominate, beat, govern, obstruct or disrupt a situation. According to Freud (Corsini, 1982) aggression is the direction of destructive tendencies of an individual towards the outside world. Aggressiveness is a reaction which emerges as a result of social miscommunication, lack of love, inhibition of the satisfaction of instincts. It can be considered a pathological symptom of psychosocial-cultural inadequacy. The aggressive behavior can be constructive or destructive. Its constructive aspect results in the dominance behavior which aims at survival; it includes various virtues such as self-confidence, self-protection, self-assertion, superiority, abuse, adjustment, curiosity, investigation, sublimation and creativity (Moses, 1996; Erikson, 1950). Its aggressive aspect; is a hostile, antagonistic behavior which hurts survival of the individual. It impairs the individual and the environment. In aggression, pleasure and domination cannot be separated from each other (Dubanosky et al. 1983). As a result, the view that the essence of aggression is based on the death instinct has lost its validity. However, this view and the assumption that death can be a source of pleasure are open to discussion.

The first signs of aggressive tendency in humans are oral instincts directed towards (1) libido, and (2) aggression (biting, chewing, spitting, crying, etc.). In the anal period, the aggressive behavior is the defecation and using this as a means to express anger. 
The aggression instinct, which motivates all behaviors with a psychic energy, and provides an energy discharge and satisfaction, varies from destructiveness to assertiveness in range (Corey, 1982). Assertiveness is a form of aggression. It is the open, honest and appropriate expression of positive or negative feelings or thoughts, responding and reacting to others feelings and thoughts in a similar fashion in human relations.

The aggression of humans and animals are different. It is difficult to explain this situation with classic instinct theory. The aggression observed in animals is a compulsory instinct which ensures the survival of the species. According to the aggression theory, aggressiveness in humans is a behavior learned by the ego as a psychic adaptation means. (Hyman et al. 1979: 1990; Kelly, 1983). Accordingly, applying/receiving corporal punishment behavior which is learned through the social-cultural process is a universal behavior which is a defense behavior of the ego and which satisfies the aggression instinct. With its constructive/destructive nature, its function to provide satisfaction is relative at individual and social level.

2. According to the Behaviorist Theory, behaviors are learned through (1) preparation, (2) trial and error, (3) reinforcement of the stimulus-reaction connection, and (4) practice. The behavior change occurs through experiences. Individual's activities and perceptions play an important part in learning through doing and experiencing. Since the nervous system is very complex in human beings, it is very difficult to objectively determine the learning process.

According to the behaviorist theory, instincts are behavioral patterns which are innate, which display characteristics of learning, but which can be changed a little or which cannot be changed at all through general methods of learning. Instincts are forms of behavior which are necessary for the continuation of life, but it is not possible to explain every behavior through them. Behaviors which are not instinctual can be learned through education or learning. In plain learning, environmental effects play an important role and restrict the individual's behaviors.

Aggression is the reaction to a certain negative stimulus. During the learning process of the individual who is influenced by the environment he lives in and who is a product of both his genes and his environment, aggressive behaviors are adopted involuntarily partially or in whole through conditioning. The intervening variables which affect the organism teach the individual to react to certain stimuli whereas the reaction (corporal punishment) is learned through continuous reinforcement. Since it is impossible to fully control the environment, it may be possible to transform aggressive behavior into assertive behavior by preparing a favorable learning environment. 
Ayla Akbash

Behaviors are shaped by positive (reward) and negative (punishment) reinforcers. In order for a behavior to be adopted, it must be rewarded. Reward and punishment during the learning process allows the transfer of knowledge and determines which reaction will be given.

The reaction association of the stimulus causes a reduction of an impulse. In this situation or in case of an unrewarded behavior, the organism gives a reaction aimed at understanding instead of an automated response. Trial and error, and building relationship between objects based on previous experiences and on mental designs and finding solutions form the foundation of learning through understanding. In case of an intense impulse or a rewarded behavior, behaviors learned previously are evaluated. In situations where previous experiences do not offer a solution, a holistic approach must be adopted. In other words, the problem is perceived by forming meaningful connections between components. In the dynamic dimension of corporal punishment, if the individual grasps the assertiveness skills and methods, aggressiveness can expire more readily. According to Chaplin and Krawiec (1970), variables which affect the perceptual learning have not been determined fully. According to Tolman, learning and behavior are separate phenomena. The individual may learn through a latent learning process, but as long as he is not motivated, he cannot adopt an assertive behavior.

Habitual behaviors are the continuity of the Stimulus - Response bond through reinforcement. In order for assertive behavior to emerge, the individual must control his aggressive behaviors and reinforce the objective behaviors which satisfy the needs he is aware of. The psychological characteristics, experiences and motivational situation of the individual play an important role here.

It is not possible to explain learning only through Stimulus-Response bond and conditioning. In the learning process, the organism must form appropriate behaviors (aggressive, assertive, self-conscious) in order to satisfy its needs in the event the homeostatic balance is disrupted. Learning is a subjective product which is specific to the individual that arises out of the intellect's abilities such as knowing, understanding, comprehending, sensing, etc.

The organism needs to know the meaning of guiding indicators (signs), the characteristics of an automated response (social and emotional), and that fear, phobia and corporal punishment can be learned (Maurer, 1976; Arık,1995). As an aggressive behavior, scolding is the precursor of a possibility of a beating. Signs are not stimuli which satisfy the reaction but are a cognitive map which guides the organism.

Levin's gestalt field concept is similar to a magnetic field in which every component is dependent on each other. The field changes as a result of learning 
and the individual perceives the stimulus in a different way. As a result of a rapid change in the field, the individual starts to behave differently. The new behavior arises intuitively.

The corporal punishment behavior which is learned through an interaction with the environment can be taken under control through the rearrangement of experiences (Dewey, 1982). It is necessary to consider an individual as a part of his environment. Learning takes place when the area of interest about which an individual is sensitive is rearranged for a certain purpose through his own experiences.

3. According to the Humanistic Theory, a human is a being that is good, rational, social, constructive, reliable, realistic, who has a capacity to actively get involved with its environment, inclined to cooperation, developing, who can accept and control oneself and who can balance his needs. However, adverse conditions which a person faces during his development may cause him to exhibit aggressive behaviors. Instead of responding automatically to every stimulus in various conditions, a person chooses the most appropriate and effective reaction that fits to his purpose. He arranges and directs his environment according to his objectives. Aggressive behaviors are adopted through learning as stipulated by behaviorism; however, they are not controlled from the outside. According to humanistic view, which defends the autonomy of human beings, and which asserts that they can make their own decisions, people take their aggressive reactions under control in order to satisfy their basic needs.

The only common basic motive of human beings is self-actualization (Rogers, 1951). All actions of a human being are directed towards the development and actualization of its skills and potentials. In contrast to Freud's id and ego concepts, self and self-conception of the organism constitute personality according to humanistic theory (Arbuckle,1970: Hart,1970). The characteristics of the id were deemed valid for the self, but the sexual and aggressive motives were considered a part of the self-actualization motive, which made the existence of these motives contentious. If self-actualization motive is a culmination of all motives, then self's characteristic must be different from that of the id. Since human beings are considered good, the characteristics of id (i.e. aggressiveness) should not be in the self. If there is aggression, a human being is not good but bad, as Freud asserts. Accordingly, it is more correct to say that a person who has managed to transform his aggression into assertiveness is a good person. This is the point where the humanistic approach gets into a tight corner. Instead of explaining the corporal punishment behavior from a motivational viewpoint, it is necessary to examine the effect of the self-conception and environmental perception style upon the individual's behaviors. The purpose of all instincts is to satisfy the need in order to 
ensure that the organism continues to exist (Rogers, 1951:1961; Falk, 1941). Since internal tendencies are directed towards integrity, and due to the fact that all perceived positive and negative experiences constitute reality, the individual endeavors to make them adaptable with the self. If a person can perceive his internal and emotional experiences and harmonize them with his self, he can accept and understand himself and other as they are. In the face of experiences which threaten it, the self uses defense mechanisms just like the ego, and protects and defends itself by changing or denying those experiences. The state of defending oneself restricts a person's freedom of learning, maturing and development. Since experiences which are not compatible with the self are perceived as threatening, aggressive reactions are a result of the organism's interaction with the environment.

The self is a dynamic process which is formed according to the way the individual perceives the experiences he has with his environment. The way in which experiences are perceived is significantly affected by the needs of being evaluated positively and accepted by others. The values of a person are a result of his thoughts and choices. As a result of the experiences which make the person happy or unhappy, the feeling of self-worth develops. Values which are internalized by the self become a part of the individual's self-evaluation system. According to Rogers (1959), the personality becomes unified if the individual's need for selfrespect and self-worthiness conditions; the self and the conception are harmonized. What is important for a person is his personality which is variable and which is directed towards an all-round development (Corey, 1982; Patterson, 1966:1967:1974 ; Shaltzer, 1974).

The acceptance of the evaluation of the individual's behavior as adaptive or aggressive by the environment by the person plays an important role of shaping the behaviors. Moving towards being adjusted is moving toward developing their potential and realizing oneself. The individual actualizes himself when there are conditions which are conducive to his development. Inclining toward aggressiveness is a situation which arises as a result of one's inability to orient, monitor and control oneself. When conditions which develop the individual from all aspects do not exist, it might be necessary to control the individual from the outside. (Greven, 1991).

\section{Perception of Corporal Punishment in the Turkish Culture}

The relationship between corporal punishment and personality theories can be observed in various proverbs and maxims. There are numerous examples regarding 
corporal punishment in Turkish proverbs (Gözütok, 1993). In accordance with the aggressiveness characteristic of id in psychoanalysis, corporal punishment has been accepted as a necessary and normal behavior with the following objectives: (1) Religious (Beating has come out of heavens; Only an infidel can defeat an atheist; a person without a religion is also without any faith, etc.) (2) Cultural (A rose will flourish wherever a mother hits a child; the ground should like her (the child) when you knock her down, her husband should like her when you marry her; A woman must look good beside his man, but she must hit the wall when he beats her, etc.). (3) Educational (A parent who does not beat her daughter will regret this (spare the rod and spoil the child); a person who does not come to his senses with advice should be reprimanded; a person who does not come to his senses with reprimand deserves a beating; a woman should always have a baby in her womb and a stick on her back (i.e. she must consistently be beaten and be pregnant), and (4) Developmental (When a wolf gets old, it becomes the laughing stock of the dogs).

According to the behaviorist approach, the child learns the corporal punishment behavior by witnessing it around him. He is involved in the violence by receiving and applying such punishment (Dinkmeyer, 1982). Since he is powerless, the child experiences and maintains the corporal punishment which is generally applied by the adults (these can be older children in the playground) as a learned behavior (Dubanoski et al. 1983). During his growth, he will also come to believe that applying corporal punishment is inevitable for gaining various psycho-social advantages such as protecting himself and his rights, satisfying his anger, dominating his environment. As for the cultural dimension, there are numerous proverbs which suggest the following: (1) All negative behavior patterns such as corporal punishment should / can be copied (if you lie down with dogs you will rise up with fleas; a rotten apple spoils the barrel; like mother, like daughter, etc.) (2) A person who has been brought up with corporal punishment (like beating slave), (3) There are certain situations in which corporal punishment is ineffective (dead mice feel no cold; a worthless vessel does not get broken, etc.) (4) Corporal punishment begets more corporal punishment (diamond cut diamond, I learned how to beat by getting beaten, etc.), (5) Negative behaviors like corporal punishment should not be copied (Do as I say, not as I do).

In the humanistic approach, a person who is aware of his aggressive tendencies should understand his and others' feelings in an emphatic way instead of applying corporal punishment, express his feelings and thoughts spontaneously, and bring a constructive approach to the relationship (Give food to someone who throws a stone at you). However, sometimes it is suggested that mercy in human relations may harm the individual (Misplaced pity may cause evil). 
Ayla Akbash

In cases where it is not possible to prevent the reception of corporal punishment, the self-respect and self-worth of the individual declines, in which case he resorts to curses as an expression of his anger and desperation (May God punish you; I leave it to God to punish you properly). There are also religious advices which aim to move the other person's conscience (if the tyrant has his cruelty, the oppressed has God on their side; do not be cursed by the oppressed, it will come true slowly). A person who is transparent and coherent in human relations and who respects both himself and others and accepts them as they are should be able to easily express his emotions and thoughts. However, there are proverbs which concern the following situations as well: (1) a person whose needs for love, care, respect, emphatic understanding, friendship, etc. have not been met by others, but who is expected to meet such needs of others (what have you given to me so that I can play for you?) (2) When a person who does not heed to others' recommendations faces corporal punishment or experiences a disaster (A good scare is worth more than good advice) (3) A person who has experienced the physiological, psychological and sociological consequences of corporal punishment can empathize with another who experienced similar things (it takes one to know one), (4) Corporal punishment is not always necessary (talking softly can bring a snake out of its pit).

\section{CORPORAL PUNISHMENT COUNSELLING MODEL}

Psychic energy may be discharged directly, indirectly or in a delayed manner based on the characteristics and attitudes of a person. Direct discharge of energy leads to corporal punishment and violence. Indirect discharge involves the redirection of psychic energy to objects and its deflection. Energy directed towards self can lead to extreme behaviors, such as suicide. A single and small stimulus is sufficient in order for the repressed or accumulated aggression energy to discharge without any consideration of time or place. Since it requires more energy to repress aggression, that energy must be channeled to productivity. In the Corporal Punishment Counseling Model, the objective is to eliminate the obstacles which stand before the satisfaction of the psychic energy and to ventilate the emotion, thus allowing the energy to be channeled towards something that is beneficial for the individual.

\section{CONCEPTS}

Need analysis; Analysis of the needs of individuals from psychological, sociological and physiological perspectives. 
Degree of psychological satisfaction; The degree in which emotional (loving, being loved, self-worth, self-confidence, self-actualization), mental (success, creativity), sociological (respectability, role and status, career, profession), economic (level of income) and physiological (sexual and other basic needs) needs are perceived and satisfied.

Response analysis; The analysis of the active/passive aggression and response based on the introverted / extroverted personality traits in the application and reception of corporal punishment.

\section{PRINCIPLES}

Objectivity; Seriousness, realism, neutrality, receptive and unjudgemental attitude during counseling sessions.

Dramatizing; During the counseling sessions, the counselor must have a supportive and guiding attitude when the corporal punishment is being dramatized by the clients. The purpose here is to ensure that the clients who cannot become aware of their behaviors comprehend better the psycho-social aspects of the corporal punishment through drama.

\section{TECHNIQUES}

Anger expression; Repetition of words the person uses during anger about corporal punishment (witch, filthy, etc. for women; henpecked, hick, etc. for men) which helps him to become aware of them.

Description of corporal punishment stimuli; The stimuli which prepare the client to the application/reception of the corporal punishment behavior, and their reasons; teaching the client the ability to discern and describe the incident, the emotion (aggression), attitude and behavior; perception, the physical, emotional, and social attribution he attaches to the real consequence - drama consequence.

Relaxation walk; The client freely walks first slowly, then briskly (individually or in groups) in order to relax physically and emotionally; the client walks shouting first "No", then "Yes"; the client walks to the rhythm of a sentence (adding emotional gestures when necessary). 
Ayla Akbash

Application of Corporal Punishment; The client demonstrates the act of receiving and applying corporal punishment verbally and physically within the group. Then he watches all members of the group perform the same actions and receives feedback about his actions.

Master-Slave Game; The clients create a real or a fictional story about corporal punishment and perform it in pairs through role playing.

a) Prisoner of Beating; Every client within the group performs a real corporal punishment reception scene which they experienced by exaggerating it with masochistic feelings.

b) Master of Beating; every client within the group performs a real corporal punishment application scene they experienced in the past by exaggerating it with sadistic feelings.

Robot Game; A part of the clients acts like a robot; then they mingle in the group and become humanized. Thus the client develops awareness about his automatic and emotional behaviors. The group forms two concentric circles. The clients in the outer circle move clockwise. As they do this, they give the clients in the inner circle (i.e. the "Robots") any shape they want. The next client in the outer group adds something to this shape. Every client gives a name to these movements. For example, if the patient in the outer circle makes the robot bend from his waist while his hands are raised in the air, he may call him "tumbler" or "digger". As the clients in the outer circle make their robots perform certain actions, they will become more human, as a result of which the clients realize that they cannot make the robots perform anything they want. They begin to think that in real life too the person opposite them may have some desires and expectations. The clients realize the effect of coercion which is used in making others perform one's desires and which underlie the application and reception of corporal punishment.

Creating a Picture; A picture is created in order to allow the client to perceive his family relations better.

a) Creating a Family Picture: A client who has a large family finds his place in the family picture which consists of the mother, father, brothers and sisters and other family members and makes comments. For example, if the client is standing between his parents, his elder brothers and sisters are standing very close and are leaning over him, the others may say that the client is in a protected position in the family.

b) Creating a Professional Picture; One of the clients tell his profession and indicates his place in the business environment. He may become aware of his relations with his co-workers, superiors, and subordinates, his position, job 
satisfaction, peace, happiness and unhappiness, loneliness, etc. at The workplace while creating this picture.

Emotion Game; Two clients come forward; others assign them a fictional role, status, profession or a quality. The counselor asks the clients to say a number of words of emotion. They start with the emotion said to them. The dialogues are improvised based on the fictitious situation. After all the emotions are performed, the changing situations, attitudes and responses are evaluated. Since the clients encounter situations which they experience in their real lives, the emotions and reactions that are performed can help them face their own real emotions, and make them realize that they perceive certain stimuli in a positive / negative way.

Drama; In the Corporal Punishment Counseling model, drama techniques are used to treat the negative effects of the corporal punishment in the client's real life.

A-Psychodrama; Acting out a problem by role-playing within a group to remedy a severe emotional disturbance caused by applying/receiving corporal punishment in real life, and to protect his mental health.

$\boldsymbol{B}$-Socio-drama: Acting out a problem by role-playing within a group remedy the social effects of applying/receiving corporal punishment in real life, and its expression from a sociological standpoint.

C-Creative Drama: The client spontaneously acts out the corporal punishment application/reception behavior which is observed, which is imitated and which has become habitual in daily life, during a group session by using his creativity.

Improvisation: The client(s) act out behaviors and stories of corporal punishment within the group without any previous preparation. He may tell a corporal punishment story or create a story about corporal punishment based on a photograph or news (Nikel, 2000)

Forum Counseling: In order for a client to find a way to balance the powers between two people within the corporal punishment reception and application function, a group watches another group while they perform a real or fictional story about corporal punishment. The performance continues until a client in the first group stops the play. The players trade places and the play resumes - this is based on the idea that the client who stops the play can perform the emotions which the play reminds him. The play may continue until other members of the audience receive feedback.

Mini-mono dramatic counseling; A member of the group expresses an emotion or his grief about a painful experience. The others create the story by asking questions to him. When role conflicts arose in the play, the course of the play is determined based on the thoughts of the audience. 
Storyteller's chair; The counselor asks a patient in the group to sit on a special chair and tell a real corporal punishment story he experienced. The other clients also sit on the same chair and tell their own stories. Every client tells his story by associating it.

Playback Counseling; The counselor asks his clients who would like to work on a corporal punishment problem. He asks the clients to perform the story with dialogues in an understated and plain manner, without changing it. Small groups are formed among those who tell their real stories to the counselor. Every group's function may be different. One group may depict the fact whereas another group may focus on problem solving. The owner of the story goes to one of these groups and tells his problem in real life. A client tells his story on the storyteller's chair. This story is performed by other clients via improvisation. This story associates other stories. If certain parts are not understood completely when the client's story is being performed, these are asked to the client and performed again. This method allows the client and others to understand the socio-psychological messages of their own stories.

Mental Workshop: In order to build group dynamics, the counselor tells the group members to freeze wherever they are while they are walking. At the first stage, the counselor tells them to walk to the center and grab a chair and to sit in pairs, chairs facing each other. Couples take turns to ask questions and introduce themselves for two minutes. A member of the volunteer couples stands behind his partner, and putting his hand on his shoulder, introduces him to the group. The counselor asks him to add lies and exaggerated characteristics to his words. At the second stage, the clients perform the exercises with slow, fast and ineffective movements, just like in real life. The counselor tells every client to think of a corporal punishment memory. They form pairs and tell these memories to their partners. One of the pairs tells the other's story to the group by adding lies and exaggerating some aspects. The story is performed through improvisations. Members of the group make comments as to what is right or wrong, complete or incomplete, real or fictional. Real and fictional situations are demonstrated as if they are all true. The counselor may tell the client to perform a behavior which associates corporal punishment. An object which is necessary for the behavior is put on the floor in the middle of the room. Every client may exhibit a spontaneous behavior that is appropriate to this object by adding a (real or fictional) meaning or story. For example, if the object is a pencil, the client may use that as a stick. Another client may see that as a knife and act accordingly. In order to allow the clients to face relational conflicts, the counselor may ask them to create scenes about the sharing of the object. They see that the emotional conflict which arises when every client tries to pull the situation to their own reality may drift to violence at a later stage. In other words, the client 
may understand that when he enters (understands) another person's reality, it is possible that the other person may also enter his reality, which would increase harmony.

Mind Voice: This activity involves the performance of the client's ideas on solutions, decisions, conflicts, worries, thoughts, and probable consequences regarding his problem from a perspective (Davis, 2000).

Event Fragment and Moments; Other clients perform a fragment of a real corporal punishment story which the client is influenced by. The moments which make the client unhappy must be put under three categories: a) Before the corporal punishment, b) During the corporal punishment, c) After the corporal punishment.

Mirror Game: This activity involves reflecting the client's words, emotions (anger, love, hate, anxiety, etc.) and his gestures to him. All of these emotions are studied in the group individually, and every group member is told to observe each other and convey the rehearsed emotion (anger) to each other. The client is thus allowed to gain insight by experiencing and feeling his emotions.

Sportive Counseling; In order to ensure that the clients relax psychologically, new behaviors are performed through games which would allow them to cope with corporal punishment. A volunteer comes forward and demonstrates a behavior. Others may interpret this behavior differently among themselves. To show this, they assume different identities and react to this behavior. Other clients take turns to participate in this game on a different level which shows this. Here the rule is to accept the role or the identity which is given and to react according to it. For example, if a patient runs towards another calling him "Dad", the other must assume the role of the father and react accordingly. The game starts with a client and stops when another client claps his hands, but resumes when the latter joins the game. When a third patient joints the game, the first one leaves. This pattern continues until the last client joins the game. The last two clients close the game. The clients are free to speak during the game.

\section{METHODOLOGY}

\section{Universe}

The universe of the research is the preparation school, ninth, tenth, and eleventh grade students attending to 24 Kasım Anatolian High School. 


\section{Sample}

The research consists of adolescents from all grades who attended to $24 \mathrm{Kasim}$ Anatolian High School and who wanted to participate in a group psychology counseling session. To this end, six boys and six girls who were between the ages of 12 and 17 were included in the study randomly. This is an experimental study.

\section{Activities}

The group met once a week for 90 to 120 minute sessions for a period of four months. Fifteen sessions were held in total. Some of the sessions lasted 3 to 3.5 hours. Psychological counseling stages of the study and its evaluation are presented below:

\section{Application}

$I^{\text {st }}$ Session: The group is shortly informed about the purpose of the psychological counseling, ethical rules of counseling, and the counseling process. The students were asked to introduce themselves and determine the rules to be followed during the counseling period. Accordingly, others would listen while one of them talked, and every member could easily express their emotions and thoughts. In the first session, it was realized that those coming from the same classes knew each other. In addition to attending to the same school, living in the same neighborhood, even on the same street, allowed them to know each other. Some of them got to know each other for the first time in this session. When the group session started, they started to communicate constantly because of this prior acquaintance and being adolescent. Therefore, the group was very dynamic. Some of the group members were silent, observant and listening. The group members explained their expectations and wishes to each other and to the counselor. They were curious as to the results of this study. A boy member said "When the group is over, you will be gentlemen. Understood?" The others disagreed with him, saying that they wanted their problems to be expressed and solved. Two members said that the objective of the group was, as it was discussed at the beginning, to improve and open up and express themselves, and they wanted the counselor to agree with them. Need and response analysis, and psychological satisfaction degrees regarding certain parts of their lives were addressed in this session.

$2^{\text {nd }}$ Session: At the beginning of the session a member reminded the rules to the group, and complained that they were not followed. This was followed by personal example analyses concerning self-discipline. Hyperactive attitudes of some members interrupted the group activities from time to time. Members told about themselves through an object of their own selection (animal, object, plant, etc.). They expressed their feelings concerning an influential life section through these objects (e.g. running horse, flying butterfly, sitting bull, working bee, lazy cat, 
sleepy monkey, stubborn goat, mad cow, raving dog, crying camel, little sparrow, crazy horse, good poodle, servant dog, angry lion, unhappy tulip, computing head, crystal vase, finger boy, etc.). Some members could not help laughing because of these names. Those who chose the dog emphasized its loyalty. They realized certain emotions prevalent in these characters such as passivity, loyalty, conformity, fear of adults, obedience, which were similar to their own emotions. Some of them chose to tell their dramatic stories through jokes and funny games and experienced catharsis. They expressed their emotions through mimes and gestures to the group. A quiet environment allowed them to turn their attention to themselves and experience their emotions. Since dramatic games helped them to relax, they started to see their talents. When they created their family picture, some of them put themselves outside their families, and realized this situation within the group, as a result of which they experienced painful emotions. Group dynamics started to develop.

$3^{\text {rd }}$ Session: In this session, the members of the group wanted to discover qualities and inner tendencies which they were not aware of. During the need analysis, they realized the level of satisfaction of their needs and started to experience emotional tides. They tried to perform response analysis by comparing their characteristics in their previous lives with their current situation. They shouted yes or no while thinking about them during free walks. They walked slowly, fast, or rhythmically, and then froze with or without a word. In other words, the members walked fast and slowly to a beat and froze sometimes under the leadership of the counselor. The words and sentences they used were both positive (I love you, my love, darling, honey, etc.) and negative (scum, germ, sleazy, crazy girl, crazy boy, maniac, etc.) and were products of their creativity. These words were expressed under the influence of positive (happy, joyous) and negative (hatred) emotions they felt at that moment. They acted on the repressed feelings related to the corporal punishment experience which they started to realize. They felt emotional satisfaction as they shouted these words and sentences at each other in groups. The girls screamed and relaxed. Unlike boys, they said they got rid of the psychological pressure they felt. They started to describe corporal punishment stimuli by using the expression of the anger. When the need relax became a priority, the counselor divided the group into two. They started to say what they wanted to each other, first slowly, then very loudly. During improvisation, a girl member put forward the idea of "retarded". When the other group shouted "retarded" back at her, she felt very bad. In another instance, the opposite group shouted "donkey eyes" at a girl who had very big black eyes, at which point she got very angry and started to cry. She said that this reaction was the psychological aspect of the corporal punishment in her family environment, and that she experienced those feelings again, and that she needed to hear beautiful words, but that nobody understood that. When the 
counselor asked, she said that she wanted others to call her "gazelle eyes" or "almond eyes". When the other group complied with her desire in the second practice, she said that this made her feel valuable. Since discharge of anger was dominant in the group atmosphere, a conflict between a boy and a girl was reflected in the group and they expressed their anger mutually. In this session, the members developed their ability to describe the psychological, sociological and physiological aspects of corporal punishment and corporal punishment stimuli, and to express their anger.

$4^{\text {th }}$ Session: In this session, the members of the group expressed the discomforts members felt (shame, hatred, shyness, revenge, curse, humiliation, losing selfrespect, being disgraced publicly) as a result of remembering and expressing these painful experiences. Due to the counselor's objectivity and dramatizing, the group members said that "in order to repair these hurt feelings," many issues which were kept secret and were not expressed a lot had to be talked about as well. To this end, both groups were divided into smaller groups and told a secret within that group. Then they told it to the larger counseling environment. A boy member who was talking about his girlfriend whom he slept together became embarrassed and left the room. The stimuli coming from the group members (gestures, facial expressions, verbal and non-verbal reactions) were also influential in his reaction. Since they had learned the basic principles of the counseling process at the beginning, they repeated that they trusted each other. A girl told that she went out with a boy who was two years younger than her. Another girl said that she had a "platonic affair" for a few months and that she entertained herself with that relation. She said that no one knew that except her. As she told this during the counseling session, she realized that "everything that is hidden turns into a secret". The group members stated that their experiences which they kept as secrets "occupied their minds" and that they were depressed by them.

A girl member said that she was tired of and angry at being followed by her neighbors, and their pressures. The group members wanted to play a game to discharge their anger. They played the master-slave game. At the end of the evaluation, they stated that they understood that they did not want to be both. A member said "A slave? Never!" They likened being a slave to certain things (objects, toilet paper, etc.). They said that they enjoyed being a master but added that this hurt their conscience. When they thought about their daily lives, they found some "master-slave behaviors" in them. A member told that he made his little brother kiss the legs of a table. Another member said she made her brother kiss her dirty socks. The girl members stated that they adopted the role of the master and made their little brothers and sisters act like slaves, and that they were sadistic. Another member said that he was the "slave of the family". According to 
his description, "he always shouted at his brother and made him cry because of the pressure coming from his mother and he had not apologized until today." The group members told him that he perceived himself as a slave while he was in fact the master and that the real slave in that relationship was his little brother. Although he realized that he was projecting his anger he felt against his mother to his brother, he said that he would never apologize (he was very angry during the session). The group members said they felt the anger caused by lack of love, which was a result of the absence of a parent (especially of a father) or of their distancing themselves from their children.

$5^{\text {th }}$ Session; Group members stated that they were nervous and stressed. They said that "Relaxation walk" "purified" them from the stressful environment outside. They talked about the definition of "personality". They examined extroverted and introverted characters. While they were analyzing their personalities, the most selfconscious male member of the group suggested that they compared themselves to an "animal or object". When the counselor asked him, he said that he likened himself to a rhino. He said that he identified with its silence and his keeping things to itself. When group members were asked to describe aggressive characteristics, everyone described their emotions, attitudes and behaviors, and gave examples . When a problem of trust arose, a "trust walk" was performed. They thought about a feeling which they held a grudge about (anger, spite, hatred, etc.) A member provided an example from the past. He said "The Arts Teacher gave me a low grade. When I protested, he scolded me. I was very angry with him." They performed this story as a play. When the scolded student became the Arts Teacher, he understood the teacher's feelings. Other members provided feedback. They released their anger in turns. They screamed. They performed an event in the first game which made them angry. When one member threw a backpack, he was called the "bag thrower". That member got angry, which made the other members laugh. A girl member called a boy member "abbas", which made him angry. He got angry whenever he was called "abbas" and this made the group nervous. Since the group process was affected, they decided to perform his behaviors. They said that they understood that his problem was a high-strung personality. In this process, "resistance elimination game" was found. Members thought about situations of "resistance breaking" in their lives. A few examples were performed and evaluated. Examples of corporal punishment were given. "Blind walk" was tried for building trust. They invented a new "game" in this session. This game involved going out and finding an object, blindfolded. They took turns to play the game. They said that they liked this game which was their invention and that they "had a blast" in this session. They were very cheerful and happy, and they thanked the counselor for the first time.

$\boldsymbol{\sigma}^{\text {th }}$ Session: In this session, examples of resistance/defense behaviors concerning 
Ayla Akbash

corporal punishment were given. A girl member said that she was very stubborn, and that everybody wanted to use violence against her, and that everyone (particularly her parents and her aunt) broke her resistance with their stubbornness. The most self-conscious member of the group said that he "broke other's resistance through passive resistance". This fact drew the attention of the entire group. $\mathrm{He}$ gave "numerous examples" while evaluating this situation, which allowed him to step outside his shyness. The group members told how their families broke their resistance. They also realized that they felt a strange pleasure in breaking their younger sibling's and other's resistance. They performed a girl member's real resistance experience: The girl was attacked by older students in the school bus and told to leave the backseat, but she resisted and did not comply. The members discussed this incident within the group. During this evaluation, they realized the element of "threat". A girl member was threatened with death victim feel like a "slave" and that they role of the master caused feelings of superiority, and that continuous verbal behavior punishment turned into corporal punishment and that it made the individual a "prisoner of beating". At the end of the session, they stated that they were emotionally drained and sad.

$7^{\text {th }}$ Session: In this session, mini-mono drama was performed. The members thought about painful experiences and feelings they went through or witnessed and told them to the group in turns. A boy member said that when he was playing ball, he had thrown the ball very fast and that it hit a four year old child. The child had fallen on the ground and taken to hospital afterwards. Another boy told that when he was fighting with another boy in his home country, his friend had come and hit the other boy in the chest, as a result of which he could not breathe for a few seconds. A girl member told an experience: she and her brother were fighting at the back seat of a car which her father was driving. Suddenly a boy with a bicycle ran in front of the car, but the father managed to stop and not hit the boy. Then he had turned to his children and said "He is a very lucky boy. I thought I would certainly hit him." The group arranged the chairs in rows to perform this scene. At first, it was staged the way the girl (A) told it. Later, the members started to exaggerate the scene. The mother's, father's, little brother's and A's roles were changed continuously. The new performers made creative contributions to the play. In the end, the scene evolved so much so that the children started to fight each other. At one point, the parents started to fight; the father hit the children on the head, to which the children reacted strongly. The little brother became the "scape goat". The member who played the father tried to silence the two kinds and their mother by force. It was a very dynamic process. All members expressed their verbal and behavioral aggression. The group members loved this drama. They witnessed how the roles of the father, mother and siblings conflicted during family fights, and how the emotional chaos and beating came into the picture by itself. The member who 
played the father said that "They deserve corporal punishment". Another one said, "Now I understand that our parents were in a very difficult situation. I understand them better now." They commented that corporal punishment was a result of lack of communication and communication conflicts. They emphasized that people needed to learn communication skills. To this end, they played "robot game" and "emotion game". They realized the differences between man and robots with respect to emotions. They realized the psychodynamic of communication conflicts and communication accidents during emotional differences and emotional chaos.

$\boldsymbol{8}^{\text {th }}$ Session: In this session, the members of the group stated that they liked the "blind walk" in the trust activity, and that they wanted to play it again. This was because the group was considerably settled and reinforced. This time they insisted on holding the other members from the waist, holding their hands, finger touch, following the finger and voice while playing. They played the game again. After that they wanted to play the "snake game", which they did. The eye contact exercise in the communication skill development activity was difficult for some members. The self-conscious member showed a "dominant" attitude. One of the girl members looked at the ceiling, as a result of which they failed to make eyecontact. When others said that they received messages from each other's eyes, some of them talked about the difficulty of not being able to make any eye-contact. During the evaluation stage, they said that they had become aware of the existence of their characteristics and messages which they had not realized before. One of them said that he perceived a girl member as a "humiliated" person while others said that they thought she was "lively". Others had perceived her as being "aggressive", but later they stated that "she was a lively girl". They said that they had understood that during the eye contact. This situation was fictionalized through psychodrama, socio-drama, and creative drama. In the end, the group members said that they started to feel that they were developing skills which allowed them to establish warm, close, sincere relations, and which enabled them to perceive stimuli correctly.

$\boldsymbol{9}^{\text {th }}$ Session: The group had made the sitting arrangement before the counselor very quickly. When talking about the possibility of lack of communication turning into corporal punishment, they concluded that discussions which started as a quarrel ended as a corporal punishment. They emphasized that there was a "scape goat" in the family. A girl member said: "It sucks being the scape goat!", which the entire group supported. They did not want to be the youngest member of a family who was always oppressed. The prevailing opinion was that "the father was fighting until the last drop of his blood to establish his authority, which he had lost". This sentence made some members laugh. Those who agreed with it said: "Why? He cannot have his children do anything. The mother is conflicting with the kids." 
With the direction of the counselor, the members only evaluated the roles. They created pictures for every member in such a conflicting family in which corporal punishment was frequently applied. They first showed their real positions and the positions of other family members as they would like them to be by making pictures. The self-conscious member had a dream of four younger brothers; so four members of the group performed this dream. B and E, two girls, had an elder brother, but they had always dreamt of and elder sister; so they created the "elder sister dream". S put the closest uncle and aunt in the picture. B put his closest grandfather and little sister in the picture. The fact that their dreams were not real and that they experienced conflicts in their real lives touched them. The unreality of the picture saddened them. They had some problems returning to the reality. These exercises continued in the form of creating a picture, creating a family picture, creating a picture of profession. At the end of the session they learned to evaluate their relationships and concluded that they had to try to be attentive to close relationships in their lives.

$10^{\text {th }}$ Session: Improvisations and forum counseling were used in this session. During evaluation, the group members provided feedback. For group of members, the "father was far away or absent". Another group complained about "mother's pressure" "brother pressure" and brother's beating. Some of them were content about their family relations. During comments about anger, a member said "they wrote dirty words on the desk" and said that he was very angry with them. The self-conscious member started to act in a relaxed manner in this session and said "let's play a game". At the end of this session, it was observed that the members were becoming aware of their behaviors and that they started to discipline themselves.

$11^{\text {th }}$ Session: In this session, mini-mono dramatic counseling and storyteller's chair were performed. Picture creation exercises were continued with. Family and school pictures were created. Based on the life fragments told by the group members, painful experiences, emotions were dramatized through asking questions, making a story and role conflict. Compared to the first sessions, the group members exhibited greater awareness, more maturity, and conscious behaviors. They started to give more sincere, rational, emotional and humanistic feedbacks.

$12^{\text {th }}$ Session: In this session, the group members took turns to tell each other's strong/weak, loved/hated characteristics, views, attitudes and behaviors. They said "he never speaks" for the self-conscious member. They called him "a good family boy". They produced creative accessories and techniques such as writing with a thumb tack on a paper; a girl member made an earring out of a thumb tack and put it on. Playback counseling and mental workshop exercises were performed in small groups. Corporal punishment experiences were performed. During pair work the 
corporal punishment experiences were improvised in an exaggerated manner. The members burst out laughing during these exercises.

$13^{\text {th }}$ Session: In this session techniques like head voice, event fragments, and moments were used. For the group members, corporal punishment experience was not something to be hidden or to be ashamed of. It turned into an experience that had to be discussed and analyzed. In the head voice exercise, the owner of the story started to analyze the corporal punishment experience that he had been obsessing over. Other members helped him. The event fragment was performed through improvisation and fiction. It was observed that the group members have started to stop worrying about the painful experiences of the past corporal punishment. They realized that they were unable to resolve the obsessed over fragments because of certain defense mechanisms (repression, denial, rationalization). They agreed that they had to fight these experiences to resolve them. They said that they felt good every time.

14th session: In this session the group members played the mirror game. The pairs expressed their negative feelings (anger, hate, disgust) and gained insight.

15th Session: In this session sportive counseling was performed and evaluation was made. They formed new behavior models for their future lives about corporal punishment. During the closing assessment, they gained insight about their strong and weak sides. A girl member underlined her resistant side, the other one stressed her fragility, another one said that he was introverted, another one said he was aggressive but he couldn't act like one . The self-conscious member said that although he was aggressive at home, he was introverted emotionally. Another member said that he tried to exhibit aggression but that he only understood the underlying reasons during these counseling sessions. Group members identified good communication skills based on their personalities. They analyzed corporal punishment experience on psychological, sociological, and corporeal dimensions. They said that they showed significant improvements in their psychological health and personal development. The counselor supported and reinforced this view. A girl the member expressed how the conclusion of the group process affected them: "We have become addicted to group counseling. It was so good. Its ending created an emptiness in us." When the counselor asked, all members said they agreed with her. The group was concluded with good wishes. It was observed that the biopsychic- social effects of the corporal punishment was eliminated through new experiences which were created during psychological counseling sessions, and that positive contributions were made to their development and psychological health. 
Ayla Akbash

\section{Discussion}

Since its beginning, the psychological counseling with this group required a high level of work which involved group processes, principles and techniques, methods, ethical rules, theoretical knowledge, skills and experience. Group psychological counseling which is performed with adolescent individuals who are experiencing a normal development and the applications which are performed with adolescents who have experienced corporal punishment in family or other social environments are different. Factors such as the psychological health of the children, their educational level, personality traits, the disadvantaged homes they come from, not having benefited from formal and non-formal education sufficiently, family structure, interfamily relationship patterns, attitudes of the parents, parents' educational level, village, neighborhood, environmental conditions, economy problems, unsatisfied needs, difficulty in adapting to adulthood may prevent the group psychological counseling from reaching its goals with respect to group dynamics, norms and processes. Creating a communication language is difficult. This fact is a disadvantage for the clients who come from families whose educational level is low, who are from subcultures, and who try to learn to express themselves and speaking skills. When they are examined with regards to their development levels, educational levels and socioeconomic levels, they can hinder healthy human relations, communication and interaction. In this period of their lives in which the formation of their character accelerates and they need assistance to solve their personality problems, their physiological needs (balanced diet, rest, sleep, recreation, accommodation), psychological needs (loving and being loved, being cared about, compassion, protection, belongingness, self-worth, commitment) and sociological needs (being a respected person, peer group, role, status, family, other social relations etc.) must be met. However, adverse family conditions make it necessary for these individuals to receive counseling with regards to education, personal development, learning a profession, and future anxiety. Even if the family is from a high economic level, the relations may become conflicted because of traditional parenting attitudes. Child education is a concept which is understood in different ways based on the characteristics of the parents. This study has demonstrated this profile. "Beating has come out of paradise" a famous Turkish proverb, reinforces the legitimacy of corporal punishment and provides support for parents. According to Walsh (1991) and Wineman (1967), corporal punishment continues to be a widespread disciplinary method. It is suggested that counseling services be provided in social (school, family, street) environments and to groups (parents, students, teachers, etc.). In addition to psychological counseling sessions, long and short term applied and theoretical studies must also be conducted. 


\section{References and notes:}

Arık,İ.A. “Öğrenme Psikolojisine Giriş”. İstanbul: Der Yayınları, 1995. ss:391-395.

Arbuckle, S. D. “Counseling: Philosophy, Theory and Practice”. Boston: Allyn and Bacon, Inc., 2. Edition, 1970.

Baler, L. "Who's in control?" New York: Poseidon Press, 1988.

Balter, L. "Who's in Control?". New York: Poseidon Press., 1988.

Committee on Psychosocial Aspects of Child and Family Health. 'Guidance for Effective Discipline'. Pediatrics, 1998;101;723.

Corsini, J. R. “Current Psychotherapies”. Itasca: F.E. Piacock Publishers, Inc., 1982.

Corey, G. "Theory and Practice of Counseling and Psychotherapy". California: Brooks/Cole Publishing Com., 1982.

Chaplin, J.P. ve T.S.Krawiec. "Systems and Theories of Psychology". 2. Bask1., London: Holt, Rinchart and Winston Inc., 1970.

Davis, D. "Uluslararası Yaratıcı Drama Sempozyumu". Geothe Instutude and Ankara University, Ankara: 2000.

Dubanoski, R., M.Inaba ve B.Gerkewicz. "Corporal Punishment in School”. 1983.

Dubanoski, R., M.Inaba ve B. Gerkewicz. "Corporal Punishment: Myths, problems and alternatives". Child Abuse and Neglect, s:7, ss.271-278., 1983.

Dinkmeyer, D. “The Parent's Handbook: Step”. Minnesota: American Guidance Service., 1982.

Elliman D ve M. A. Lynch. 'The physical punishment of children'. http://adc.bmj.com/ content/83/3/196.full.html\#ref-list-1

Ertan, Y. ve C. Ardalı. "Saldırganlık, Şiddet ve Terörün Psikososyal Yapıları”. COGİTO, Şiddet, İstanbul: Yapı-Kredi Yayınları, 1996, 11.Bask1, S:6-7, ss.143-163.

Erikson, E. "Childhood and Society". New York: W. W. Norton., 1950.

Egerton, J. "Back to Basics". Current, s:186, ss.27-33, 1976. 11. Friedman, A. ve D. Friedman. "Parenting : A Developmental Process". Pediatric Annuel, S:6, ss. 564-578., 1977.

Falk, H. "Corporal Punishment: A Social Interpretation of Its Theory and Practice in the School of the United States". New York: Teachers College Press., 1941.

Greven, P. "Spare the Child: The Religious Roots of Punishment and the Psychological Impact of Physical Abuse". New York: Random House, 1991.

Gözütok, F. 'Okulda Dayak'. Ankara: 72 Ofset, 1993.

Hyman, I. "Reading, Writing and the Hickory Stick: The Appalling Story of Physical Violence in American Schools". Boston: Lexington Books., 1990.

Hyman, I. ve J.Wise. "Corporal Punishment in American Education". Philadelphia: Temple University Press, 1979.

Hart, J.T. ve T.M. Tomlinson. "New Directions in Client-Centered Therapy". Boston: Houghten Mifflin Com., 1970.

Kelly, J. "Solving your Child's Behavior Problems: An Everyday Guide for Parents". Toronto: Little, Brown and Company, 1983. 
Moses, R. "Şiddet Nedere Başlıyor?” Çev: Ayşe Kuş. COGíTO, Şiddet, İstanbul: YapıKredi Yayınları, 1996, 11.Bask1, ss: 23-26.

Maurer, A. "Personal Communication". 1976.

Nickel W. H. "Uluslararası Yaratıcı Drama Sempozyumu". Geothe Instutude and Ankara University, Ankara: 2000.

Nobes G. ve M. Smith. 'Family Structure and the Physical Punishment of Children'. Journal of Family Issues 2002 23: 349.

Nobes G. ve M. Smith. 'The Relative Extent of Physical Punishment and Abuse by

Mothers and Fathers'. Trauma Violence Abuse 2000 1: 47.

http://tva.sagepub.com/content/1/1/47

Patterson, C.H. "Relationship Counseling and Psychotherapy". New York: Harper and Row Publishers, 1974.

Patterson, C.H. "Theories of Counseling and Psychotherapy". New York: Harper and Row Inc., 1966.

Patterson, C.H. "Relationship Theory and/or Behavior Therapy". Presented at the Annual Convention, American Personnel and Guidance Association. Dallas: March, 1967.

Paley, V. "White Teacher”. Massachugetts: Harvard University Press, 1979.

Riak, J. "Plain Talk Abaut Spanking”. Booklet Available fram PTAUE. 1979.

Rogers, C.R. "Client-Centered Therapy”. Boston: Houghton Miffin, 1951.

Rogers, C.R. On Becoming A Person: A Therapist's View or Psychotherapy”. Boston: Houghton Mifflin Com., 1961.

Shartzer, B. ve S. C. Stone. "Fundamentals of Counseling". Boston: Houghton Mifflin Com., 1974.

Taylor, C.A.ve ark. 'Parents' Professional Sources of Advice Regarding Child Discipline and Their Use of Corporal Punishment'. Clinical Pediatrics, 52(2) 147-155. http://cpj.sagepub.com

Walsh, K. "Discipline for Character Development". Alabama: R.E.P. Books, 1991.

Wineman, D. ve A. James "Policy Statement: Corporal Punishment in the Public School". Detroit: Metropolitan Detroit Branch of the American Civil Liberties Union of Michigan, 1967. 


\title{
SUMMARY
}

\section{Examination of Corporal Punishment from Three Perspectives: A Recommended Corporal Punishment Counseling Model and its Application}

\begin{abstract}
Ayla Akbash
Kocaeli University, Turkey

The corporal punishment has been examined through three different of perspectives, and a new psychological counseling model has been suggested for corporal punishment. The suggested model (CPC) has been applied in a psychological counseling group therapy. Consequently, new psycho-social developments such as behaviors, attitudes, emotions, opinions and experiences thoughts related to corporal punishment have been observed. Counseling sessions and evaluations have been presented in the study as well.
\end{abstract}

Keywords: Corporal punishment, psychological counseling model 